\title{
Update on DOE's Nuclear Energy University Program
}

\section{8th International Conference on Methods and Applications of Radioanalytical Chemistry (MARC VIII)}

\author{
M. J. Lambregts
}

\section{April 2009}

The INL is a

U.S. Department of Energy

National Laboratory

operated by

Battelle Energy Alliance

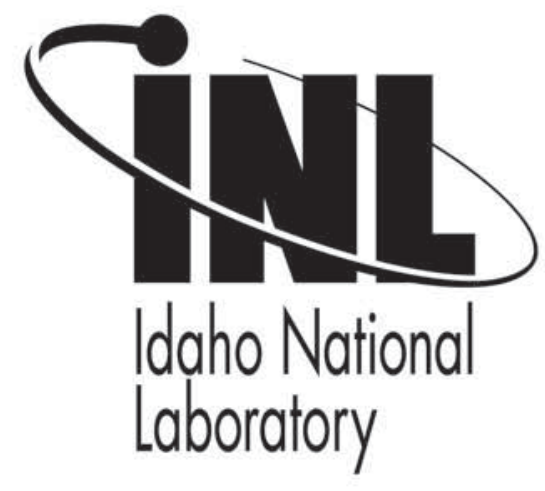

This is a preprint of a paper intended for publication in a journal or proceedings. Since changes may be made before publication, this preprint should not be cited or reproduced without permission of the author. This document was prepared as an account of work sponsored by an agency of the United States Government. Neither the United States Government nor any agency thereof, or any of their employees, makes any warranty, expressed or implied, or assumes any legal liability or responsibility for any third party's use, or the results of such use, of any information, apparatus, product or process disclosed in this report, or represents that its use by such third party would not infringe privately owned rights. The views expressed in this paper are not necessarily those of the United States Government or the sponsoring agency. 


\title{
Update on DOE's Nuclear Energy University Program
}

\author{
M.J. Lambregts \\ Idaho National Laboratory, Center for Advanced Energy Studies
}

Idaho Falls, ID 83415

\begin{abstract}
The Center for Advanced Energy Studies (CAES) Nuclear Energy University Program Office assists the U.S. Department of Energy Office of Nuclear Energy (DOENE) by administering its University Program. To promote accountable relationships between universities and the TIOs/TDOs, a process was designed and administered which includes two competitive Requests for Proposals (RFP's) and two FOAs in the following areas: (1)Research and Development Grants, (2)Infrastructure improvement, and (3)Scholarships and Fellowships. NEUP will also host periodic reviews of university mission-specific $\mathrm{R} \& \mathrm{D}$ that document progress, reinforce accountability, and assess return on investment; sponsor workshops that inform universities of the Department's research needs to facilitate continued alignment of university R\&D with NE missions; and conduct communications activities that foster stakeholder trust, serve as a catalyst for accomplishing NEUP objectives, and provide national visibility of NEUP activities and accomplishments. Year to date efforts to achieve these goals will be discussed.
\end{abstract}

\section{Introduction}

A rebirth of interest in nuclear energy is underway in the United States and across the world, driven by concern to secure safe energy supplies and to mitigate consequences of global climate change. Not only government but also private industry and U.S. academic institutions have made substantial investments to support expansion and the rebirth of nuclear power.

Recent research activities, however, have not been fully integrated to achieve optimal benefits. In FY 2009, NE addressed this need by restructuring the Nuclear Education and Research Initiative (NERI) program to create the new NE University Programs (NEUP). Through NEUP, NE will better integrate university research with technical programs, producing outcomes relevant to the Nation's interests. NEUP's objectives include the following:

- Addressing technical nuclear energy R\&D challenges

- Maintaining the Nation's global leadership position in nuclear energy R\&D

- Advancing the state of U.S. nuclear science and technology

- Enhancing the Nation's nuclear science and engineering infrastructure to prepare the nuclear industry for future expansion

To realize its mission, NEUP is helping addresses a significant challenge faced by the nuclear industry: meeting its human capital, educational, and research needs. Acquiring a welltrained workforce is crucial to the development and operation of existing and proposed nuclear plants, yet the United States is beginning to experience significant shortfalls with regard to its science and engineering labor force. Approximately one quarter of active U.S. scientists and engineers are nearing retirement age within the next 5 years, and - despite NERI's past successes - student enrollments are still lower than needed to replace the current workforce, let alone support a nuclear renaissance. 


\section{Discussion}

NEUP emphasizes enhancing the quality of nuclear science and engineering education, cultivating and expanding the trained workforce that supports expansion of U.S. nuclear power. Following are NE's goals for the U.S. education system:

- Attracting the brightest and best students to nuclear professions

- Integrating R\&D efforts of national laboratories, industry, and universities in the revitalization of nuclear education

- Facilitating transfer of knowledge from the current aging nuclear workforce to the next generation of nuclear workers, including technicians, engineers, and scientists.

As with NERI, NEUP projects will correlate with current DOE-NE-sponsored programs: Generation IV, AFCI, and NHI. In addition, DOE-NE is supporting two new initiatives: the Light Water Reactor Sustainability program, which develops knowledge to predict changes in a nuclear power plant environment over time; and the Plutonium-238 Development program, which seeks to produce plutonium-238 domestically for use in radioisotope power systems. Through NEUP, DOE-NE will also sponsor investigator-initiated research that furthers the principal R\&D missions.

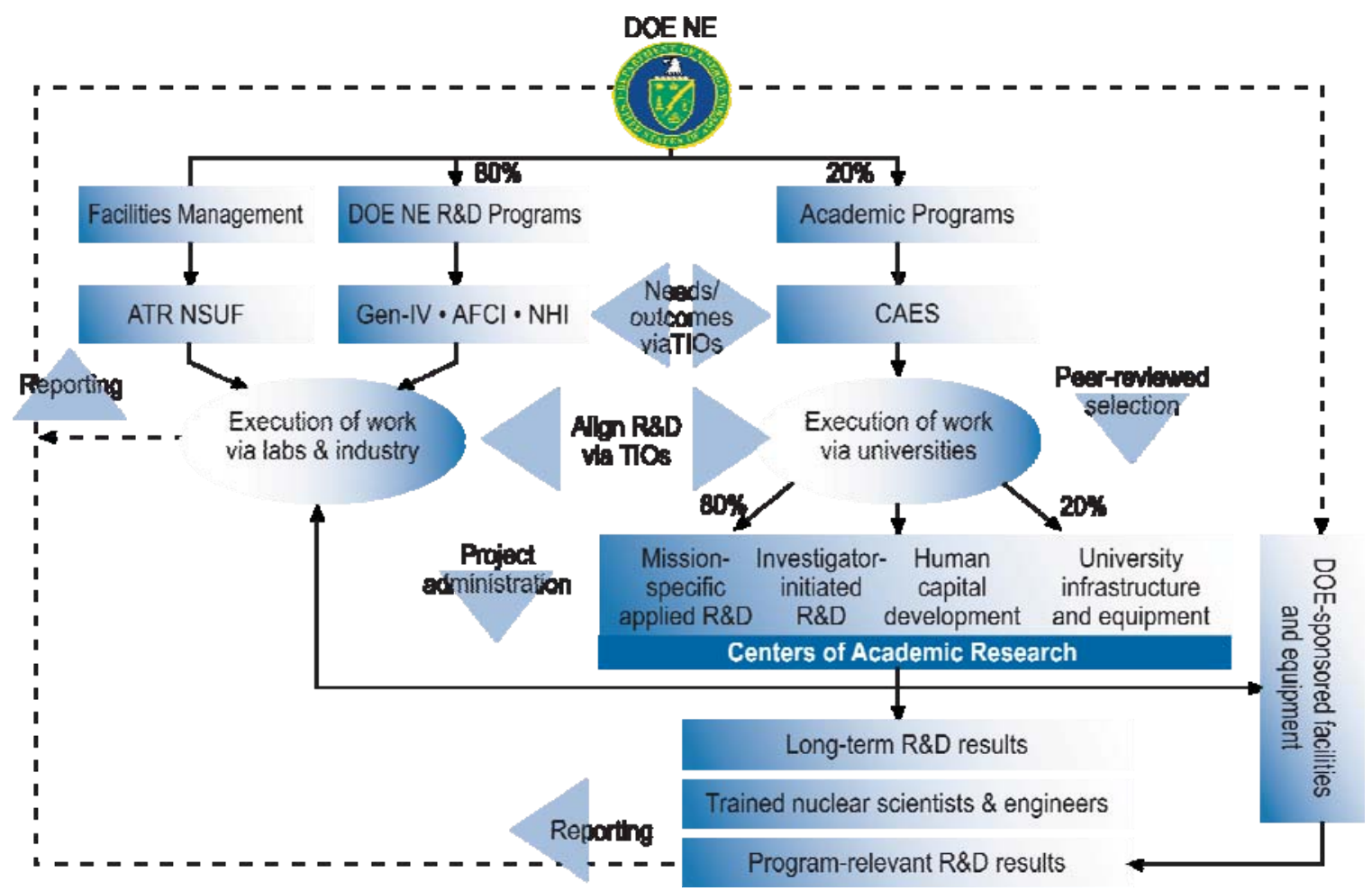

The Nuclear Energy University Programs Office will provide NEUP with administrative support, ensuring the university program's successful implementation. The NEUP office will facilitate technical integration of NE university programs within NE R\&D programs. The office will undertake such activities as administering proposal processes, implementing review and selection processes, and hosting reviews of university R\&D. The above figure illustrates the new NEUP integrated approach. 
The Center for Advanced Energy Studies (CAES) houses the NEUP program. Steps have been taken to ensure there is no conflict of interest through using Idaho National Laboratory administrative staff to execute the program; the NEUP director is a university representative.

\begin{tabular}{|c|c|}
\hline Program Office Staff & Position \\
\hline $\begin{array}{c}\text { Dr. John Gilligan, North Carolina State } \\
\text { University/INL (joint appointment) }\end{array}$ & NEUP Director \\
\hline Dr. Marsha Lambregts, INL & NEUP Relationship Manager/Program Manager \\
\hline Ms. Kortny Rolston, INL & NEUP Communication/Outreach Coordinator \\
\hline Ms. Cindi Jensen, INL & NEUP Review Coordinator \\
\hline
\end{tabular}

NEUP supports university R\&D and infrastructure development, promoting accountable relationships between universities, technology integration offices (TIOs), and technology development offices (TDOs). For example, the R\&D process will begin each year with a workshop: NE program managers, TIOs, TDOs, and stakeholders from the university and industrial communities will meet to determine research needs of NE programs. The workshop ensures alignment between NE research programs and university R\&D programs, enables program-relevant production, and enhances quality and availability of nuclear engineering and science professionals.

In FY 2009, the Department of Energy's Nuclear Energy Research and Development programs allocated $20 \%$ of their appropriated funding to the universities through NEUP. Originally, the budget was expected to be $\sim \$ 34 \mathrm{M}$ spread across five programmatic areas (and the NERI mortgages). However, funding was not appropriated for 2009 until March and it proved to be far greater than expected: $\$ 64.7 \mathrm{M}$ and more limited in scope, eliminating the plutonium-238 programmatic area and severely limiting the light water reactor sustainability and the nuclear hydrogen initiative areas.

Eighty percent of this funding was to be distributed through competitive R\&D subcontracts to US universities. These contracts replace grants and cooperative agreements for R\&D to better promote accountability and better integrate the research into the programs. Each subcontract will have an assigned point of contact within the programs to provide technical oversight and integration.

\section{Funding Breakdown: Total Funding \$64.7M}

\begin{tabular}{|l|c|}
\hline NERI Mortgages & $\$ 19.9 \mathrm{M}$ \\
\hline R\&D Subcontracts & $\$ 39.9 \mathrm{M}$ Total \\
& $\$ 14.9 \mathrm{M}$ AFCI \\
\hline
\end{tabular}




\begin{tabular}{|l|l|}
\hline & $\$ 25 \mathrm{M}$ GEN IV \\
\hline Infrastructure & $\sim \$ 6 \mathrm{M}$ \\
\hline Scholarships and Fellowships & $\sim \$ 2.45 \mathrm{M}$ \\
\hline
\end{tabular}

Fiscal accountability is also built into the process as scope, schedule and costs will be tracked through quarterly and annual reports to the program office. Subcontracts will be between the selected lead universities and Battelle Energy Alliance on behalf of the Department of Energy-Nuclear Energy Office.

NEUP received a total of 433 pre-applications. These were submitted by 131 principal and collaborating research organizations including 87 universities, 11 national laboratories, 25 industrial businesses, and 8 foreign institutions. These represented 37 US states and the District of Columbia, 7 foreign countries and 4 minority institutions. Two hundred sixteen preapplications were recommended for full application submission.

To support NEUP's efforts toward human capital and infrastructure development, solicitations will be made for scholarship and fellowship programs, as well as for support of nuclear science and engineering infrastructure needs of colleges and universities. The Infrastructure piece of NEUP will be conducted as a grant or cooperative agreement. NEUP will assist the DOE-Idaho office with the development of the solicitation (through a Funding Opportunity Announcement (FOA)) and panel review of the proposals.

The Scholarship and Fellowship solicitations will be conducted in two pieces. The first piece is a Funding Opportunity Announcement conducted by the DOE-Idaho operations office in conjunction with the NEUP program office. Again, NEUP will assist the DOE-Idaho office in the development of the solicitation and panel review of the proposals. The solicitation will involve the development of a cooperative agreement between DOE and Colleges and Universities with programs in Nuclear Engineering and related Sciences such as Health Physics, Materials Science, Radiochemistry, Nuclear Chemistry or Nuclear Physics who will accept NEUP scholarship and fellowship funds under the established terms and conditions. The second piece will be the Request for Applications from the students who desire a scholarship or fellowship. This will be a competitive process conducted by the NEUP program office. This solicitation will be similar to the National Science Foundation process. A panel will judge the students upon their intellectual merit and broader impacts of their proposed projects as they relate to the programs of Nuclear Energy. The students must be registered to attend one of the Colleges and Universities accepted under the FOA to be considered for a scholarship or fellowship.

\begin{tabular}{|l|c|}
\hline Program Element & Date \\
\hline 2008 Workshop & $11 / 20-25 / 08$ \\
\hline R\&D Pre-application Release & $12 / 18 / 08$ \\
\hline
\end{tabular}




\begin{tabular}{|l|c|}
\hline R\&D Pre-application Close & $1 / 19 / 09$ \\
R\&D Full Application Release & $2 / 6 / 09$ \\
R\&D Full Application Close & $3 / 23 / 09$ \\
R\&D Announcement & $5 / 4 / 09$ \\
\hline Infrastructure Request for Proposals (RFP) Release & $3 / 11 / 09$ \\
Infrastructure RFP Close & $4 / 15 / 09$ \\
Infrastructure Announcement & $6 / 15 / 09$ \\
\hline Scholarship and Fellowship University RFP Release & $4 / 2 / 09$ \\
Scholarship and Fellowship University RFP Close & $5 / 4 / 09$ \\
Scholarship and Fellowship University Announcement & $6 / 15 / 09$ \\
\hline Scholarship and Fellowship Student Request for & $4 / 17 / 09$ \\
Applications (RFA) Release & \\
Scholarship and Fellowship Student RFA Close & $5 / 22 / 09$ \\
Scholarship and Fellowship Student RFA & $6 / 15 / 09$ \\
\hline Announcement & $8 / 13-14 / 09$ \\
\hline 2009 Workshop (Salt Lake City) & \\
\hline
\end{tabular}

NEUP will also promote the program's communications and outreach. Effective communication fosters stakeholder trust, augments integration and collaboration, serves as a catalyst for accomplishing NE objectives, and provides national visibility of NEUP accomplishments. NEUP will work to place select scholarship and fellowship recipients within the national laboratory system as interns and as full-time employees.

\section{Conclusions}

NEUP's outreach plan will help build awareness in the industry and the Nation. The university program contributes to a larger effort to strengthen U.S. education and research and invests in innovative education to improve U.S. competitiveness in the global economy. The United States has historically been a leader in nuclear technology - an increasingly important element in addressing today's changing energy needs. With government, industry, and universities playing significant roles in realizing nuclear power's potential, NE's new program will play a vital role in meeting the demand created by a burgeoning nuclear renaissance. 